\title{
Concurrent chemoradiation with capecitabine and weekly irinotecan as preoperative treatment for rectal cancer: results from a phase I/II study
}

\author{
G Klautke ${ }^{*, 1}$, U Küchenmeister', T Foitzik ${ }^{2}$, K Ludwig ${ }^{3}$, F Prall ${ }^{4}$, E Klar ${ }^{2}$ and R Fietkau' \\ 'Department of Radiotherapy, University of Rostock, University Hospital, Südring 75, 18059 Rostock, Germany; ${ }^{2}$ Department of Surgery, University \\ Hospital, Rostock, Germany; ' Department of Surgery, Klinikum Südstadt, Rostock, Germany; ${ }^{3}$ Department of Pathology, University Hospital, Rostock, \\ Germany
}

The aim of this study was to investigate the efficacy and safety of chemoradiation using capecitabine and irinotecan as neoadjuvant therapy for patients with rectal cancer. Conventional radiation was given at daily fractions of I.8 Gy on 5 days a week for a total dose of $55.8(50.4+5.4) \mathrm{Gy}$. Concurrently, irinotecan $40 \mathrm{mg} \mathrm{m}^{-2}$ once weekly and capecitabine continuously at dose levels of 500,650 , 750 and $825 \mathrm{mg} \mathrm{m}^{-2}$ twice daily were administered. Surgery was performed 4-6 weeks following completion of chemoradiation. A total of 28 patients (3 UICC II, 25 UICC III) were enrolled and all received treatment. Dose-limiting toxicity was diarrhoea grade IV and hand-foot syndrome at the $825 \mathrm{mg} \mathrm{m}^{-2}$ dose level. The maximum tolerated dose of capecitabine was $750 \mathrm{mg} \mathrm{m}^{-2}$. Diarrhoea was the most common toxicity: grade III in nine patients. Two patients died, one due to pneumonia and one due to sudden cardiac death. A complete response and only microfocal residual tumour disease was achieved in four and three patients (27\%). In all, 25 of 28 patients undergoing surgery, 24 (96\%) had R0 resection. Preoperative chemoradiation based on continuous daily capecitabine and weekly irinotecan appears to tolerated and effective in patients with rectal cancer.

British Journal of Cancer (2006) 94, 976-981. doi:I0.1038/sj.bjc.6603053 www.bjcancer.com

Published online 2I March 2006

(c) 2006 Cancer Research UK

Keywords: rectal cancer; neoadjuvant chemoradiotherapy; capecitabine; irinotecan

Achieving tumour resection with clear margins (R0) is the most important prognostic factor in rectal carcinoma and the principal objective of treatment (Hermanek and Wittekind, 1994) while maintaining faecal continence is an important objective for maintaining patients' quality of life. In locally advanced rectal cancer (LARC), it can be difficult or impossible to achieve both of these objectives and local recurrence and metastases can be a major problem following curative surgery (Hurby et al, 2003). Radiotherapy or chemoradiation has been widely used to improve patient outcomes in locally advanced rectal cancer (LARC), 5-FUbased chemoradiation is an effective treatment, shown by many phase II studies (Chen et al, 1994; Kaminsky-Forrett et al, 1998; Janjan et al, 1999; Crane et al, 2003). Preoperative chemoradiation increases the resection rate (Reerink et al, 2003) and preoperative radiation or chemoradiotherapy decrease local recurrence and reduce small bowel complications compared with postoperative therapy (Minsky et al, 1992; Frykholm et al, 1993, Sauer et al, 2004). R0 resection rates of $60-85 \%$ have reported with 5-FUbased preoperative chemoradiation for LARC (Videtic et al, 1998; Küchenmeister et al, 2000; Rödel et al, 2000).

Continuous infused application of 5-FU significantly improves overall and disease-free survival compared with bolus administra-

*Correspondence: Dr G Klautke;

E-mail: gunther.klautke@med.uni-rostock.de

Received 12 December 2005; revised 22 February 2006; accepted 22 February 2006; published online 2I March 2006 tion of 5-FU (O'Connell et al, 1994). However, infused application is inconvenient and is associated with an increased risk of adverse venous events, such as infection or thrombosis, and most cancer patients prefer oral chemotherapy (Liu et al, 1997). Capecitabine, an oral, tumour-activated fluoropyrimidine carbamate, delivers 5 -FU preferentially to tumour cells via enzymatic conversion. The final step of this process is mediated by the enzyme thymidine phosphorylase (TP), which is significantly upregulated in tumour tissue compared with healthy tissue (Schüller et al, 2000). TP expression is also enhanced by radiotherapy and the in vivo antitumour activity of radiotherapy and capecitabine is more than additive compared with either agent alone (Sawada et al, 1999). Twice-daily oral administration of capecitabine enables chronic dosing that results in continuous exposure to 5-FU without requiring central venous access. As first-line therapy for MCRC, capecitabine results in superior response rates, improved safety, and improved convenience compared with 5-FU/LV (Mayo Clinic regimen) (Van Cutsem et al, 2004). Capecitabine was also continuously applicated, concurrent to radiotherapy preoperatively with good results (Dunst et al, 2002).

The topoisomerase I inhibitor irinotecan has shown consistent efficacy in both chemotherapy-naive patients and 5-FU-pretreated patients with metastatic colorectal cancer (Douillard et al, 2000; Saltz et al, 2000). Also radiosensitizing properties even under hypoxic conditions were documented (Boothmann et al, 1987; Boscia et al, 1993), and Irinotecan has also shown in combination with 5-FU and radiation preoperatively in patients with LARC 
consistent efficacy in local control and DFS (Mehta et al, 2003; Klautke et al, 2005). As a result of that, it was a logical step to investigate the combination of capecitabine and irinotecan in patients with LARC.

The aim of this study was to define the maximum tolerated dose (MTD), dose-limiting toxicity (DLT) and safety profile of capecitabine in combination with irinotecan and radiotherapy as preoperative chemoradiation in patients with LARC.

\section{PATIENTS AND METHODS}

This was an open-label, 6-week study of increasing dose levels of capecitabine given concurrently with irinotecan and standard whole pelvic irradiation as preoperative therapy for rectal cancer clinical UICC stage II or III.

\section{Patient eligibility}

Male and female patients aged 18-75 years were prospectively enrolled in the study if they presented with histologically confirmed nonmetastatic adenocarcinoma of the rectum at an UICC stage II or III. Other inclusion criteria were measurable disease (at least one bidimensionally measurable tumour lesion), WHO performance status $\leqslant 2$, adequate haematological, hepatic and renal function, and a life expectancy of at least 3 months. Pregnant or lactating women, patients with unresolved bowel obstruction or ileus/subileus and those with a history of chronic diarrhoea were excluded.

All patients underwent baseline examination and staging according to the recommendations of the German Cancer Society within 2-4 weeks prior to the start of chemoradiation, including history and physical examination, complete blood count, serum chemistry profile, chest X-ray, rectoscopy or sigmoidoscopy, endoluminal ultrasound, abdominal ultrasound and computed tomography (CT) of the abdomen and pelvis. Inclusion of a minimum of 10 patients in the phase II part and a minimum of 15 patients at the recommended dose level was planned.

The study was approved by the local ethics committee, and written informed consent was obtained from all patients.

\section{Treatment}

CT-assisted 3-dimensional planning of radiation therapy was employed. The patients underwent CT with $5 \mathrm{~mm}$ slices, contrast administration to bladder, rectum and small intestine, and endoscopic clipping (Riepl et al, 2000) of the upper and lower border of the tumour performed immediately prior to planning. Radiation therapy was given with photons from a linear accelerator with energy $>6 \mathrm{MV}$. The target volume comprised the areas at risk including the presacral space along the posterior bladder or vaginal wall, respectively, and the common iliac lymph nodes until and including the fifth lumbar vertebral body. Radiotherapy was delivered with three or four fields using an isocentric technique with individually collimated field portals. Daily fractions of $1.8 \mathrm{~Gy}$ (calculated at the ICRU 50 reference point) were given on 5 days a week over 5 weeks to a total dose of $50.4 \mathrm{~Gy}$. An additional lowvolume boost of $5.4 \mathrm{~Gy}$ was given in three fractions to the site of the primary tumour after previous contrast radiography of the small intestine.

Radiotherapy was administered with concurrent chemotherapy consisting of weekly doses of irinotecan $40 \mathrm{mg} \mathrm{m}^{-2}$, given over 90 min on days $1,8,15,22,29$ and 36. Patients also received capecitabine twice daily at 12 -h intervals at the following dose levels: 500,650 and $825 \mathrm{mg} \mathrm{m}^{-2}$. As the increase from the 650 to the $825 \mathrm{mg} \mathrm{m}^{-2}$ twice daily capecitabine dose level proved to be too large during the course of the study, in an amendment a further dose level of $750 \mathrm{mg} \mathrm{m}^{-2}$ twice daily was introduced before the dose was increased to $825 \mathrm{mg} \mathrm{m}^{-2}$. So all steps of increasing the dose from $500 \mathrm{mg} \mathrm{m}^{-2}$ to $825 \mathrm{mg} \mathrm{m}^{-2}$ twice daily capecitabine were performed adequately.

At the first dose level three patients were planned. If no DLT occurred, again three patients were planned at the next dose level. If any DLT occurred, another three patients were treated at the same dose level. If there was again a DLT, the level below was the recommended dose level. If there was no DLT another three patients at the next dose level were planned.

Patients were monitored by history, clinical examination and blood examination on every Monday and Thursday during the treatment period.

The chemotherapy was interrupted if any DLT occurred and was continued at $75 \%$ of the original dose when toxicity resolved to grade I or II. In a case of diarrhoea grade IV radiation and chemotherapy were interrupted and were continued when diarrhea resolved to grade II with radiation and $50 \%$ of the original dose of chemotherapy.

Restaging and surgery using total mesorectal excision was to be performed within 4-6 weeks after completion of chemoradiotherapy. Following surgery, a postoperative adjuvant chemotherapy according to the recommendations of the German Cancer Society was recommended to all patients.

\section{Dose-limiting toxicity}

Toxicity was graded according to the National Cancer Institute Common Criteria (NCI-CTC, version 3.0). Defined DLTs included: grade IV diarrhoea despite appropriate treatment with antidiarrhoea drugs; grade IV haematological side effects; grade IV mucositis; any other acute side effect at grade IV; severe nausea; vomiting 6-10 times a day despite the use of antiemetics.

\section{Data evaluation}

The deadline for data evaluation was June 30, 2005. Statistical analysis including survival analysis according to Kaplan-Meier was performed with the SPSS software package. Survival was calculated from the date of histologic verification of diagnosis to the patient's death or the date of last follow-up. Progression-free survival was calculated from diagnosis to the time of first detection of new lesions or progression of residual lesions.

\section{RESULTS}

\section{Patient characteristics}

Between July 2002 and May 2004, we recruited 28 patients (16 women and 12 men) aged from 48 to 75 years (median, 64 years) who met all the inclusion criteria. Baseline patient and tumour characteristics are shown in Table 1. There were two cases of a primary tumour stage uT2, all lymph node positive, 18 cases of uT3, all beside two lymph node positive and eight cases at stage uT4, seven endosonography assessed the lymph node status as positive. The median length of the tumour, as an approximate measure of the tumour mass, was $7 \mathrm{~cm}$ (range $3-15 \mathrm{~cm}$ ). In all, 14 tumours started in the lower third of the rectum, 12 in the middle and two in the upper third.

\section{Safety}

Dose-limiting toxicities did not occur at each of the three patients at the 500,650 and $750 \mathrm{mg} \mathrm{m}^{-2}$ twice daily dose levels but were observed at the $825 \mathrm{mg} \mathrm{m}^{-2}$ twice daily dose. The first three patients experienced one grade IV diarrhoea with the $825 \mathrm{mg} \mathrm{m}^{-2}$ twice daily dose. The next three patients at this dose level also reported one grade IV diarrhoea and 1 dose-limiting hand-foot syndrome. So three further patients were treated at the $750 \mathrm{mg} \mathrm{m}^{-2}$ 
twice daily dose level and no DLT occurred. Therefore, the recommended dose level was $750 \mathrm{mg} \mathrm{m}^{-2}$ bid capecitabine, concurrently during radiation and weekly irinotecan $\left(40 \mathrm{mg} \mathrm{m}^{-2}\right.$, six times). Another 10 patients were included in the phase II part at this dose level (see Table 2).

The most common toxicity was diarrhoea: grade IV in two patients at a dose level of $825 \mathrm{mg} \mathrm{m}^{-2}$ and grade III in nine patients

Table I Baseline patient characteristics

\begin{tabular}{|c|c|c|}
\hline \multirow[b]{2}{*}{ Variable } & \multicolumn{2}{|c|}{ Patients $(N=28)$} \\
\hline & No. & $\%$ \\
\hline \multicolumn{3}{|l|}{ Gender } \\
\hline Male & 12 & 43 \\
\hline Female & 16 & 57 \\
\hline \multicolumn{3}{|l|}{ Age (years) } \\
\hline Range & $48-75$ & \\
\hline Median & 64 & \\
\hline \multicolumn{3}{|l|}{ T stage } \\
\hline uT2 (uNo/uN+) & $2(0 / 2)$ & 7 \\
\hline uT3 (uNo/uN+) & $18(2 / 16)$ & 64 \\
\hline uT4 (uNo/uN+) & $8(1 / 16)$ & 29 \\
\hline \multicolumn{3}{|l|}{$N$ stage } \\
\hline uNO & 3 & 11 \\
\hline $\mathrm{uN}+$ & 25 & 89 \\
\hline \multicolumn{3}{|c|}{ Tumour localization (cm from anal verge) } \\
\hline $0-5$ & 14 & 50 \\
\hline $5.5-10$ & 12 & 43 \\
\hline$>10$ & 2 & 7 \\
\hline \multicolumn{3}{|l|}{ Tumour length $(\mathrm{cm})$} \\
\hline Range & $3-15$ & \\
\hline Median & 7 & \\
\hline \multicolumn{3}{|l|}{ Initial Hb value } \\
\hline$<13.5 \mathrm{~g} \mathrm{dl}^{-1}$ & 13 & 46 \\
\hline$\geqslant 13.5 \mathrm{~g} \mathrm{dl}^{-1}$ & 15 & 54 \\
\hline
\end{tabular}

(32\%). In addition, four patients (14\%) had fever (raised temperature of over $38.5^{\circ} \mathrm{C}$ ), which could be easily controlled with usual antibiotics. One patient in the phase I part died of pneumonia, contracted in the intensive care unit, 2 months after treatment was discontinued early as a result of dose-limiting grade IV diarrhoea. During the phase II part of the study, one patient died as a result of a 5-FU-related sudden cardiac death on day 5 of treatment. There were no grade IV haematological toxicities and the only grade III haematological toxicity was a single case of leucopenia (see Table 2). Other toxicity like oral mucositis, hepatic or renal dysfunction was not observed.

After surgery there was only one anastomotic leakage, treated by reoperation, and one bowel atony after extirpation, treated conservatively reported.

\section{Resection}

Of the 28 patients enrolled, 25 underwent surgery, two patients died and one patient did not have surgery because of systemic progress (peritoneal carcinosis; dose level $500 \mathrm{mg} \mathrm{m}^{-2}$ twice daily). Of these 25 patients, an $\mathrm{R} 0$ resection was possible in 24 cases (96\%); one patient underwent a R1 resection during the first dose level of $500 \mathrm{mg} \mathrm{m}^{-2}$ (he received additional low-volume radiotherapy in combination with capecitabine and irinotecan and, as of June 2005, he is free of distant metastases and local recurrences). Of the 14 patients with tumours in the lower third $(0-5 \mathrm{~cm})$, seven patients had sphincter involvement, so five $(36 \%)$ underwent sphincter-sparing surgery, the remaining nine patients underwent abdominoperineal resection. Of the patients with tumours in the middle third of the rectum $(5.1-10 \mathrm{~cm})$, one required abdominoperineal resection, while the others were able to undergo sphincter-sparing surgery (Table 3 ).

\section{Response}

Downstaging for the $\mathrm{T}$ category was analysed in 25 patients, who underwent surgery (Table 4), and response was analysed in the 26 patients who were alive (including one patient who did not undergo surgery due to systemic progress). Overall, four patients $(15 \%)$ had pathological complete response (pCR), and further

Table 2 Inicdence and maximum toxicity grade (CTC) according to capecitabine dose levels

\begin{tabular}{|c|c|c|c|c|c|c|c|c|c|c|c|c|c|c|c|c|c|c|c|c|}
\hline $\begin{array}{l}\text { Capecitabine dose } \\
\text { Toxicity grade (CTC) } \\
\text { Number of patients }\end{array}$ & \multicolumn{4}{|c|}{$500 \mathrm{mg} \mathrm{m}^{-2}$ bid } & \multicolumn{4}{|c|}{$650 \mathrm{mg} \mathrm{m}^{-2}$ bid } & \multicolumn{8}{|c|}{ Phase I } & \multicolumn{4}{|c|}{$\begin{array}{c}\text { Phase II } \\
750 \mathrm{mg} \mathrm{m}^{-2} \text { bid }\end{array}$} \\
\hline \multicolumn{21}{|l|}{ Hematologic } \\
\hline Anemia & 3 & 0 & 0 & 0 & 3 & 0 & 0 & 0 & 5 & I & 0 & 0 & 6 & 0 & 0 & 0 & 8 & 2 & 0 & 0 \\
\hline \multicolumn{21}{|l|}{ Laberatory } \\
\hline Hyperbilirubinaemia & 3 & 0 & 0 & 0 & 3 & 0 & 0 & 0 & 6 & 0 & 0 & 0 & 6 & 0 & 0 & 0 & 10 & 0 & 0 & 0 \\
\hline ALAT/ASAT & 3 & 0 & 0 & 0 & 3 & 0 & 0 & 0 & 6 & 0 & 0 & 0 & 6 & 0 & 0 & 0 & 10 & 0 & 0 & 0 \\
\hline \multicolumn{21}{|l|}{ Gastrointestinal } \\
\hline Nausea/vomiting & 3 & 0 & 0 & 0 & 3 & 0 & 0 & 0 & 4 & 2 & 0 & 0 & 5 & I & 0 & 0 & 8 & 2 & 0 & 0 \\
\hline
\end{tabular}

One patient died of pneumonia in the intensive care unit, after a complete resolved diarrhoea grade IV in the phase I, 2 months after treatment had interrupted; one patient died as a result of a 5-FU related sudden cardiac death on day 5 of treatment in the phase II. 
three cases (12\%) had only minimal microfocal residual disease (MRD). Pathological partial response (pPR) was achieved in additional 16 patients $(62 \%)$. In one patient, disease progression was systemic (peritoneal carcinosis) rather than local at the $500 \mathrm{mg} \mathrm{m}^{-2}$ twice daily dose level. pCRs were observed at the $750 \mathrm{mg} \mathrm{m}^{-2}$ twice daily dose level (three cases) and $825 \mathrm{mg} \mathrm{m}^{-2}$ twice daily level (one case); the MRD cases arose at 650, 750 and $825 \mathrm{mg} \mathrm{m}^{-2}$ (one case at each dose level; Table 5). It is noteworthy that all the pCR and MRD cases occurred in patients with an initial haemoglobin value above the median value of $13.5 \mathrm{~g} \mathrm{dl}^{-1}$. The length of the tumour did not affect the pCR and MRD, nor did the $\mathrm{uT}$ or uN stage.

\section{Disease control and survival}

All the patients who underwent surgery are alive after a median observation period of 24 months. One R0 resection patient with his tumour in the lower third had a local recurrence after 7 months, one patient had metastases in the liver, which had not been seen during imaging and were diagnosed during surgery. Another patient developed liver metastases after 18 months. One patient developed metastases in the lung after 6 months, another after 15 months. As a result of the short follow-up period the rating of statistical analysis for survival must be with care. The DFS (30 months) for all patients who underwent surgery is $78 \%( \pm 8 \%)$, the local control $96 \%$ ( $\pm 4 \%)$, the OS $100 \%$.

Table 3 Surgical approach by tumour height

\begin{tabular}{lccc}
\hline & \multicolumn{3}{c}{ Surgical approach (no. patients) } \\
\cline { 2 - 4 } $\begin{array}{l}\text { Tumour } \\
\text { heigt (cm) }\end{array}$ & Sphincter - saving & $\begin{array}{c}\text { Abdominop. } \\
\text { Resection }\end{array}$ & Total \\
\hline $0-5$ & 5 & 9 & 14 \\
$5.5-10$ & 11 & 1 & 12 \\
$>10$ & 2 & 0 & 2 \\
\hline
\end{tabular}

Table 4 Pathologic downstaging of the primary tumor

\begin{tabular}{lcccccr}
\hline & \multicolumn{5}{c}{$\begin{array}{c}\text { Pathological T stage at } \\
\text { time of surgery (patients) }\end{array}$} \\
\cline { 2 - 7 } Clinical T stage at baseline & pT0 & pTI & pT2 & pT3 & pT4 & Total \\
\hline CT2 & 0 & 1 & 1 & 0 & 0 & 2 \\
CT3 & 4 & 0 & 6 & 6 & 0 & 16 \\
CT4 & 2 & 0 & 2 & 3 & 0 & 7 \\
Total & 6 & 1 & 9 & 9 & 0 & 25 \\
\hline
\end{tabular}

\section{DISCUSSION}

Preoperative chemoradiation has the potential to increase resectability and improve local control in patients with LARC. In addition, it can enable patients to undergo more conservative sphincter-sparing surgery and there is a lower rate of acute side effects (Sauer et al, 2004). Up to now, it is not known if preoperative chemoradiation had to be intensified with capecitabine, irinotecan or oxaliplatin for better survival data. So the remission rates are used to compare the different studies of preoperative-intensified chemoradiotherapy, and also knowing, that a complete remission to radiation or chemoradiation is associated with favourable survival (Janjan et al, 2001).

The rate of complete remission is about $10 \%$ by using 5 -FU or capecitabine concurrent to radiotherapy (Dunst et al, 2002; Sauer et al, 2004), by adding irinotecan or oxaliplatin the rate of complete remission in phase II studies can be more than doubled (overview by Klautke et al, 2005).

Other studies investigate the combination of preoperative capecitabine and irinotecan concurrent to radiotherapy (Table 6), too. The average dose of irinotecan during the period of radiotherapy was in most studies about $240-250 \mathrm{mg} \mathrm{m}^{-2}$. Looking at the capecitabine dose and application time, there were more differences between these studies. So Hofheinz et al (2005) applicates $500 \mathrm{mg} \mathrm{m}^{-2}$ bid of capecitabine (day 1-38; total dose of capecitabine: $38000 \mathrm{mg} \mathrm{m}^{-2}$ ) and reported a high rate of pCR (4/ $19 ; 21 \%)$ and MRD $(5 / 19 ; 26 \%)$, and a R0 resection rate of $100 \%$. Gollins (Gollins et al, 2005) applicates $825 \mathrm{mg} \mathrm{m}^{-2}$ bid from day 1 to 33 continuously (total dose of capecitabine: $54450 \mathrm{mg} \mathrm{m}^{-2}$ ) together with four times irinotecan $\left(60 \mathrm{mg} \mathrm{m}^{-2}\right)$. After surgery there was a R0 resection in $94 \%$ and a pCR in $20 \%(4 / 20)$. At this dose level there was no DLT. In our study, we saw DLT at a dose of six times irinotecan $\left(40 \mathrm{mg} \mathrm{m}^{-2}\right)$ and capecitabine $825 \mathrm{mg} \mathrm{m}^{-2}$ bid from day 1-43 (total dose of capecitabine in the dose level with DLT: $70950 \mathrm{mg} \mathrm{m}^{-2}$; total dose of capecitabine in the recommended dose level: $64500 \mathrm{mg} \mathrm{m}^{-2}$ ) and we saw the DLT mostly in the fifth week. The rate of pCR (15\%) and R0 - resection seems to be comparable with these other studies.

In nearly all these studies diarrhoea was the DLT. The haematological toxicity is not common, in these regimes, and also oral mucositis was not reported. The hand-foot syndrome was also no common toxicity at the different recommended doses of capecitabine. Comparing these results with the results of the combination 5-FU as continuous infusion and irinotecan weekly concurrently to radiotherapy (Mitchell et al, 2001; Mehta et al, 2003; Klautke et al, 2005) there were no real differences in efficacy and toxicity. So the rate of pCR was about $24-37 \%$, and diarrhoea was the most common toxicity with grade III about $30 \%$. Mitchell reported also intravenous catheter infections and thrombi as DLT. And these catheter complications are the big disadvantage of continuous infused 5-FU and the big advantage of capecitabine.

Table 5 Pathohistological response of 25 patients underwent surgery depending on the dose level of capecitabine

\begin{tabular}{|c|c|c|c|c|c|}
\hline \multirow[b]{3}{*}{ Pathohistological response } & \multicolumn{4}{|c|}{ Phase I } & \multirow{2}{*}{ Phase II } \\
\hline & \multicolumn{4}{|c|}{ Capecitabine dose (bid) } & \\
\hline & $500 \mathrm{mg} \mathrm{m}^{-2}$ & $650 \mathrm{mg} \mathrm{m}^{-2}$ & $750 \mathrm{mg} \mathrm{m}^{-2}$ & $825 \mathrm{mg} \mathrm{m}^{-2}$ & $750 \mathrm{mg} \mathrm{m}^{-2}$ \\
\hline NC & 2 & 0 & 0 & 0 & 0 \\
\hline pPR & 0 & 2 & 5 & 3 & 6 \\
\hline MRD & 0 & । & 0 & । & । \\
\hline Total & 2 & 3 & 6 & 5 & 9 \\
\hline
\end{tabular}


Table 6 Overview of phase I or phase I/II studies with preoperative chemoradiotherapy using capecitabine and irinotecan concurrent to radiation

\begin{tabular}{|c|c|c|c|c|c|c|c|c|}
\hline Study & $\begin{array}{c}\text { No of } \\
\text { patients }\end{array}$ & $\begin{array}{l}\text { Capecitabine } \\
\left(\mathrm{mg} \mathrm{m}^{-2} \text { bid) }\right.\end{array}$ & $\begin{array}{c}\text { Irinotecan } \\
\left(\mathrm{mg} \mathrm{m}^{-2} / \text { week }\right)\end{array}$ & $\begin{array}{c}\text { Radiotherapy } \\
\text { (Gy) }\end{array}$ & PCR (\%) & PCR+MRD & RO & DLT \\
\hline $\begin{array}{l}\text { Hofheinz et al } \\
\text { (2005) }\end{array}$ & 19 & $\underline{500 / 625}$ & 50 & $45+5,4$ & 21 & $4+5 / 19$ & $19 / 19$ & Diarrhoea \\
\hline Gollins et al (2005) & 20 & $\begin{array}{l}650 / 825 \\
\text { Day } \frac{1-33}{1-}\end{array}$ & $\frac{50 / 60 / 70}{4 x}$ & 45 & 20 & $4+4 / 20$ & $16 / 17$ & $\begin{array}{l}\text { Diarrhoea } \\
\text { Neutrope nic } \\
\text { fever }\end{array}$ \\
\hline \multirow{2}{*}{$\begin{array}{l}\text { Becerra et al } \\
(2005)\end{array}$} & 12 & 850 & $30 / 40 / 50$ & $45+5,4$ & & & & Study is ongoing \\
\hline & & $\begin{array}{l}\text { Day I-5; 5,5 } \\
\text { weeks }\end{array}$ & $5 \times$ & & & & & \\
\hline $\begin{array}{l}\text { Kennedy et al } \\
(2004)\end{array}$ & 12 & $500 / 650 / 800$ & 40 & $45+5,4$ & 8 & $1+2 / 12$ & $12 / 12$ & Study is ongoing \\
\hline Present study & & Day I-43 & $6 \times$ & & & & & $\begin{array}{l}\text { Hand-feet } \\
\text { syndrome }\end{array}$ \\
\hline
\end{tabular}

The underlined dose is the recommended dose level.

It is a great discussion whether oxaliplatin or irinotecan is the best partner in the preoperative chemoradiotherapy together with capecitabine and radiation and unfortunately there is no effort for a randomized trial to clear this discussion. The rate of complete response does not differ using oxaliplatin or irinotecan, but critics mark the high rate of diarrhoea as disadvantage to irinotecan. Analysing at the study from Duck et al (2004) using $825 \mathrm{mg} \mathrm{m}^{-2}$ capecitabine bid on each day of radiation, and weekly $50 \mathrm{mg} \mathrm{m}^{-2}$ oxaliplatin concurrent to radiation, the most frequent grade III/IV toxicity was diarrhoea in $22 \%$. The pCR was $6 \%(1 / 17)$. Using continuous infused 5-FU over the whole time of radiation together with oxaliplatin concurrent to radiotherapy, diarrhoea also is a DLT (Loi et al, 2005), or was reported in $16 \%$ by a pCR of $28 \%(7 / 25)$ (Aschele et al, 2005).

\section{REFERENCES}

Aschele C, Friso ML, Pucciarelli S, Lonardi S, Sartor L, Fabris G, Urso ED, Del Bianco P, Sotti G, Lise M, Monfardini S (2005) A phase I-II study of weekly oxaliplatin, 5-fluorouracil continuous infusion and preoperative radiotherapy in locally advanced rectal cancer. Ann Oncol 16: 1140-1146

Becerra CR, Cho L, Gregoreyk S, Simmang C, Frenkel EP, Verma UN (2005) A Phase I study with irinotecan, capecitabine and radiation therapy for patients with locally advanced or metastatic rectal cancer. Proc Am Soc Clin Oncol (Abstr 212)

Boothmann DA, Trask DK, Pardee AB (1987) Inhibition of potential lethal damage repair in human tumor cells by lapachone, an activator of topoisomerase I. Cancer Res 49: 605-612

Boscia RE, Korbut T, Holden SA, Ara G, Teicher BA (1993) Interaction of topoisomerase I inhibitors with radiation in cis-diamminedichloroplatinum (II)-sensitive and - resistant cells in vitro and in the FSAIIC fibrosarcoma in vivo. Int J Cancer 53: $118-123$

Chen ET, Mohiuddin M, Brodovsky H, Fishbein G, Marks G (1994) Downstaging of advanced rectal cancer following combined preoperative chemotherapy and high dose radiation. Int J Radiat Oncol Biol Phys 30: 169-175

Crane CH, Skibber JM, Feig BW, Vauthey JN, Thames HD, Curley SA, Rodriguez-Bigas MA, Wolff RA, Ellis LM, Delclos ME, Lin EH, Janjan NA (2003) Response to preoperative chemoradiation increases the use of sphincter-preserving surgery in patients with locally advanced low rectal carcinoma. Cancer 97: 517-524
The preoperative chemoradiotherapy with capecitabine $750 \mathrm{mg} \mathrm{m}^{-2}$ bid, concurrently during radiation (days 1-43) and weekly irinotecan $40 \mathrm{mg} \mathrm{m}^{-2}$ (six times) seems to be safe and effective. We need a longer follow-up to verify a potential benefit for survival in comparing with historical collectives of patients.

\section{ACKNOWLEDGEMENTS}

This work was supported in part by a grant from Aventis Pharma $\mathrm{GmbH}$, Bad Soden am Taunus, Germany and Hoffmann-La Roche AG, Grenzach - Wyhlen, Germany.

Douillard JY, Cunningham D, Roth AD, Navarro M, James RD, Karasek P, Jandik P, Iveson T, Carmichael J, Alakl M, Gruia G, Awad L, Rougier P (2000) Irinotecan combined with fluorouracil compared with fluorouracil alone as first-line treatment for metastatic colorectal cancer: a multicentre randomised trial. Lancet 355: $1041-1047$

Duck LR, Sempoux C, Honhon B, Coster B, Coche J-C, Kerger J, Canon J-L, Humblet Y, Scalliet P, Machiels J-P (2004) A phase II study of preoperative oxaliplatin, capecitabine, and external beam radiotherapy in patients with locally advanced rectal adenocarcinoma. Proc Am Soc Clin Oncol (Abstr 3552)

Dunst J, Reese T, Sutter T, Zuhlke H, Hinke A, Kolling-Schlebusch K, Frings S (2002) Phase I trial evaluating the concurrent combination of radiotherapy and capecitabine in rectal cancer. J Clin Oncol 20: $1005-1009$

Frykholm GJ, Glimelius B, Pahlman L (1993) Preoperative or postoperative irradiation in adenocarcinoma of the rectum: Final treatment results of a randomized trial and an evaluation of late secondary effects. Dis Colon Rectum 36: $564-572$

Gollins SW, Myint S, Levine E, Morris J, Haylock B, Susnerwala S, Saunders M, Biswas A (2005) Phase I study of radiotherapy (RT) plus concurrent irinotecan (CPT-11) and capecitabine (CAP) as preoperative downstaging treatment for locally advanced inoperable rectal cancer. Proc Am Soc Clin Oncol (Abstr 3565) 
Hermanek P, Wittekind C (1994) The pathologist and the residual tumor (R) classification. Pathol Res Pract 190: 115-123

Hofheinz R, von Gerstenberg-Helldorf B, Wenz F, Gnad U, KrausTiefenbacher U, Muldner A, Hehlmann R, Post S, Hochhaus A, Willeke F (2005) Phase I trial of capecitabine and weekly irinotecan in combination with radiotherapy for neoadjuvant therapy of rectal cancer. J Clin Oncol 23: 1350-1357

Hurby G, Barton M, Miles S, Carroll S, Nasser E, Stevens G (2003) Site of local recurrence after surgery, with or without chemotherapy, for rectal cancer: Implication for radiotherapy field design. Int J Radiat Oncol Biol Phys 55: $138-143$

Janjan NA, Crane C, Feig BW, Cleary K, Dubrow R, Curley S, Vauthey JN, Lynch P, Ellis LM, Wolff R, Lenzi R, Abbruzzese J, Pazdur R, Hoff PM, Allen P, Brown T, Skibber J (2001) Improved overall survival among responders to preoperative chemoradiation for locally advanced rectal cancer. Am J Clin Oncol 24: 107-112

Janjan NA, Khoo VS, Abbruzzese J, Pazdur R, Dubrow R, Cleary KR, Allen PK, Lynch PM, Glober G, Wolff R, Rich TA, Skibber J (1999) Tumor downstaging and sphincter preservation with preoperative chemoradiation in locally advanced rectal cancer: The M.D. Anderson Cancer Center experience. Int J Radiat Oncol Biol Phys 44: 1027-1038

Kaminsky-Forrett MC, Conroy T, Luporsi E, Peiffert D, Lapeyre M, Boissel P, Guillemin F, Bey P (1998) Prognostic implications of downstaging following preoperative radiation therapy for operable T3-T4 rectal cancer. Int J Radiat Oncol Biol Phys 42: 935 -941

Kennedy AS, Kwok Y, Batko-Yovino S, Van Echo DA (2004) A phase I study of preoperative capecitabine, irinotecan concurrent with radiation therapy for resectable rectal cancer. Proc Am Soc Clin Oncol (Abstr 268)

Klautke G, Feyerherd P, Ludwig K, Prall F, Foitzik T, Fietkau R (2005) Intensified concurrent chemoradiotherapy with 5-fluorouracil and irinotecan as neoadjuvant treatment in patients with locally advanced rectal cancer. Br J Cancer 92: 1190-1197

Küchenmeister U, Kirchner R, Mellert J, Klautke G, Mucke R, Hopt UT, Fietkau R (2000) Erste Ergebnisse der neoadjuvanten simultanen Radiochemotherapie bei fortgeschrittenen Rektumkarzinomen. Strahlenther Onkol 176: 560-566

Liu G, Franssen E, Fitch M, Warner E (1997) Patient preferences for oral versus intravenous palliative chemotherapy. J Clin Oncol 15: 110-115

Loi S, Ngan SY, Hicks RJ, Mukesh B, Mitchell P, Michael M, Zalcberg J, Leong T, Lim-Joon D, Mackay J, Rischin D (2005) Oxaliplatin combined with infusional 5-fluorouracil and concomitant radiotherapy in inoperable and metastatic rectal cancer: a phase I trial. Br J Cancer 92: $655-661$

Mehta VK, Cho C, Ford JM, Jambalos C, Poen J, Koong A, Lin A, Bastidas JA, Young H, Dunphy EP, Fisher G (2003) Phase II trial of preoperative 3D conformal radiotherapy, protracted venous infusion 5-fluorouracil, and weekly CPT-11, followed by surgery for ultrasound-staged T3 rectal cancer. Int J Radiat Oncol Biol Phys 55: 132-137

Minsky BD, Cohen AM, Kemeny N, Enker WE, Kelsen DP, Reichman B, Saltz L, Sigurdson ER, Frankel J (1992) Combined modality therapy of rectal cancer: decreased acute toxicity with the preoperative approach. J Clin Oncol 10: 1218-1224

Mitchell EP, Anne P, Fry R, Ahmad N, Boman B, Edmunston T, Rakinic J, Goldstein S, Rose L, Palazzo J, Cagir B, Kovatich A, Hauck W, Fishel R, Bonanni R, Hoey D, Rose D, Curran W (2001) Combined mortality therapy of locally advanced or recurrent adenocarcinoma of the rectum: report of a phase I trail of chemotherapy with CPT-11, 5-FU and concomitant irradiation. Proc Am Soc Clin Oncol (Abstr 519)

O'Connell MJ, Martenson JA, Wieand HS, Krook JE, Macdonald JS, Haller DG, Mayer RJ, Gunderson LL, Rich TA (1994) Improving adjuvant therapy for rectal cancer by combining protracted-infusion fluorouracil with radiation therapy after curative surgery. N Engl J Med 331: $502-507$

Reerink O, Verschueren RCJ, Szabo BG, Hospers GA, Mulder NH (2003) A favourable pathological stage after neoadjuvant radiochemotherapy in patients with initially irresectable rectal cancer correlates with a favourable prognosis. Eur J Cancer 39: $192-195$

Riepl M, Pietsch A, Klautke G, Fehr R, Fietkau R (2000) Endoscopic pretherapeutic clipping for gastrointestinal tumors. A method for exact definition of the target volume. Strahlenther Onkol 176: 517-523

Rödel C, Grabenbauer GG, Schick C, Papadopoulos T, Hohenberger W, Sauer R (2000) Präoperative simultane Radiochemotherapie mit 5Fluorouracil bei lokal fortgeschrittenen T4-Rektumprimärtumoren. Strahlenther Onkol 176: $161-167$

Saltz LB, Cox JV, Blanke C, Rosen LS, Fehrenbacher L, Moore MJ, Maroun JA, Ackerland SP, Locker PK, Pirotta N, Elfring GL, Miller LL (2000) Irinotecan plus fluorouracil and leucovorin for metastatic colorectal cancer. Irinotecan Study Group. N Engl J Med 343: 905-914

Sauer R, Becker H, Hohenberger W, Rodel C, Wittekind C, Fietkau R, Martus P, Tschmelitsch J, Hager E, Hess CF, Karstens JH, Liersch T, Schmidtberger H, Raab R, German Rectal Cancer Study Group (2004) Preoperative versus postoperative chemoradiotherapy for rectal cancer. $N$ Engl J Med 351: 1731 - 1740

Sawada N, Ishikawa T, Sekiguchi F, Tanaka Y, Ishitsuka H (1999) X-ray irradiation induces thymidine phosphorylase and enhances the efficacy of capecitabine (Xeloda) in human cancer xenografts. Clin Cancer Res 10: $2948-2953$

Schüller J, Cassidy J, Dumont E, Roos B, Durston S, Banken L, Utoh M, Mori K, Weidekamm E, Reigner B (2000) Preferential activation of capecitabine in tumor following oral administration to colorectal cancer patients. Cancer Chemother Pharmacol 45: 291-297

Van Cutsem E, Hoff PM, Harper P, Bukowski RM, Cunningham D, Dufour P, Graeven U, Lokich J, Madajewicz S, Maroun JA, Marshall JL, Mitchell EP, Perez-Manga G, Rougier P, Schmiegel W, Schoelmerich J, Sobrero A, Schilsky RL (2004) Oral capecitabine vs intravenous 5-fluorouracil and leucovorin: integrated efficacy data and novel analyses from two large, randomized, phase III trials. Br J Cancer 90: 1190-1197

Videtic G, Fisher B, Perera FE, Bauman GS, Kocha WI, Taylor M, Vincent MD, Plewes EA, Engel CJ, Stitt LW (1998) Preoperative radiation with concurrent 5-fluorouracil continuous infusion for locally advanced unresectable rectal cancer. Int J Rad Oncol Biol Phys 42: 319-324 